\title{
FEDERAL CRIMINAL PROCEDURE-WITHDRAWAL OF GUILTY PLEAS
}

Under what conditions a criminal defendant shall be permitted to withdraw his plea of guilty ${ }^{1}$ is a recurring problem of the criminal law. ${ }^{2}$ Numerous practical considerations militate against indiscriminate withdrawal of guilty pleas. Injustice, however, would result from an unfailing refusal to permit withdrawal. Any detailed legislative definition of the situations in which withdrawal should be permitted may exclude deserving cases. Rule 32(d) of the Federal Rules of Criminal Procedure incorporates these divergent policies in a generalized statement which gives the trial court broad discretion to allow withdrawal of a guilty plea. ${ }^{3}$ It provides as follows:

A motion to withdraw a plea of guilty or of nollo contendere may be made only before sentence is imposed or imposition of sentence is suspended; but to correct manifest injustice the court after sentence may set aside the judgment of conviction and permit the defendant to withdraw his plea. ${ }^{4}$

This comment will discuss the cases arising under Rule 32(d) and its predecessor, Rule $\Pi(4)$ of the Criminal Appeals Rules of $1933 . .^{5}$ More particularly, it will consider: (1) misrepresentation or mistake of the defendant's attorney as a ground for the withdrawal of a guilty plea, (2) the relevance of allegations or proof concerning the defendant's innocence to the disposition of his motion to withdraw the plea, (3) the effect of a change in law subsequent to the entry of a plea, (4) the effect of delay by the defendant in moving that his plea be withdrawn, and (5) the extent to which the trial court's discretion is reviewable by appellate courts. The cases will be discussed without regard to whether the

${ }^{1}$ Plea of guilty as used in this comment includes a plea of nollo contendere. Consult Farnsworth v. Zerbst, 98 F. 2d 541 (C.A. 5th, 1938).

2 As early as 1807 a federal court on its own motion gave a defendant in a capital case the right to withdraw his plea. United States v. Dixon, 25 Fed. Cas. 872, No. 14,968 (C.C. D.C., 1807).

${ }^{3}$ In addition to the Federal Rule this solution was adopted by the American Law Institute in its Model Code of Criminal Procedure $\$ 230$ (official draft, 1930), which is remarkably similar in effect to Rule 32(d).

${ }^{4}$ Fed. Rules Crim. Proc. 32(d) (1946). Rule II(4) of the Criminal Appeals Rules of 1933 read: "A motion to withdraw a plea of guilty shall be made within ten (10) days after entry of such plea and before sentence is imposed." 18 U.S.C.A. $\S 688$ (1940). Consult Whitman, Federal Criminal Procedure 239 (1950). Cases decided under both the present and former rules will be considered together since the same considerations of justice were applied under Rule II(4) that were made explicit in Rule 32(d).

${ }^{5}$ In thirty-eight reported cases under both Rule 32(d) and Rule II(4), only four have permitted withdrawal while thirty-four have denied it. Under Rule II(4) one case granted withdrawal and nine denied it, while under Rule 32(d) three motions have been granted and twenty-five denied. Such figures, however, may be misleading since many motions addressed to the discretion of the court go unappealed and unreported. Particularly is this true with respect to motions decided for the defendant in the first instance since there is slight probability of appeal. 
motion was made before or after sentence where it is clear that the same principles apply. ${ }^{6}$

Under Rule 32(d) withdrawal of the plea is not a right of the defendant but a matter within the discretion of the court. ${ }^{7}$ The reason is apparent: defendants should not be allowed to gamble on a light sentence and then, upon losing, be allowed to insist upon the right to gamble on a jury trial. A contrary conclusion which would, in effect, indiscriminately afford defendants an opportunity for two days in court rather than the usual one was succinctly rejected by Judge Learned Hand in United States v. Paglia: "Justice is not a game."8

The grounds upon which the trial court's discretion will be exercised to permit the withdrawal of a plea cannot be stated with any real certainty. Of the variety of grounds relied upon by defendants the most usual, repeatedly held insufficient, is surprise at the severity of the sentence imposed. ${ }^{9} \mathrm{An}$ extreme case is Stidham v. United States ${ }^{10}$ where the defendant, accused of transporting a stolen car from Alabama to Missouri, pleaded guilty and purported to throw himself on the mercy of the court. The judge imposed a four-year sentence. The defendant then remarked that he had not received much mercy and moved to withdraw his plea on the ground that he had stolen the car in Louisiana. He was without counsel at the proceedings by his own request and did not realize the indictment charged only that he had transported the car. The court denied the motion, set aside the four-year sentence and substituted the maximum five. On appeal all the actions of the trial court were upheld. A more recent holding to the same effect is Friedman $v$. United States ${ }^{11}$ where the only grounds advanced for the motion were that the defendant misconceived the seriousness of the offense and that he had a defense to the charge. The motion was denied, the court

${ }^{6}$ The motion is addressed to the discretion of the court whether made before or after sentence. Cases cited note 7 infra. Cases under Rule 32(d) involving pre-sentence motions include United States v. Panebianco, 208 F. 2d 238 (C.A. 2d, 1953); Williams v. United States, 192 F. 2 d 39 (C.A. 5th, 1951); Goo v. United States, 187 F. 2d 62 (C.A. 9th, 1951). A large majority involve post-sentence motions.

7 United States v. Panebianco, 208 F. 2d 238 (C.A. 2d, 1953); Friedman v. United States, 200 F. 2 d 690 (C.A. 8th, 1952); Goo v. United States, 187 F. 2d 62 (C.A. 9th, 1951); Williams v. United States, 192 F. 2d 39 (C.A. 5th, 1951); Mitchell v. United States, 179 F. 2d 305 (C.A. 5th, 1950); United States v. Lias, 173 F. 2d 685 (C.A. 4th, 1949); Stidham v. United States, 170 F. 2d 294 (C.A. 8th, 1948); Katz v. United States, 161 F. 2d 869 (C.A. 6th, 1947); United States v. Harris, 160 F. 2d 507 (C.A. 2d, 1947); United States v. Mignogna, 157 F. 2d 839 (C.A. 2d, 1946); Bergen v. United States, 145 F. 2d 181 (C.A. 8th, 1944); United States v. Colonna, 142 F. 2d 210 (C.A. 3d, 1944); Farrington v. King, 128 F. 2d 785 (C.A. 8th, 1942); Farnsworth v. Zerbst, 98 F. 2d 541 (C.A. 5th, 1938); United States v. Denniston, 89 F. 2d 696 (C.A. 2d, 1937).

8190 F. 2d 445, 447 (C.A. 2d, 1951).

9 Friedman v. United States, 200 F. 2d 690 (C.A. 8th, 1952); Williams v. United States, 192 F. 2d 39 (C.A. 5th, 1951); United States v. Norstrand Corp., 168 F. 2d 481 (C.A. 2d, 1948); Stidham v. United States, 170 F. 2d 294 (C.A. 8th, 1948); United States v. Harris, 160 F. 2d 507 (C.A. 2d, 1947); United States v. Colonna, 142 F. 2d 210 (C.A. 3d, 1944).
10170 F. 2d 294 (C.A. 8th, 1948).
11200 F. 2d 690 (C.A. 8th, 1952). 
holding that surprise at the severity of the sentence was not sufficient in the absence of proof that the misconception was the fault of the trial court, the prosecution or, perhaps, the defendant's attorney.

Ordinarily the cases contain grounds in addition to surprise at the severity of the sentence, and the sufficiency of these other grounds is the main issue. A defendant may plead that he was induced to enter a guilty plea by the prosecution, or that his attorney, either appointed by the court or of his own choosing, induced him to enter a guilty plea by misrepresenting to him the law or the severity of the offense. A defendant may accompany his motion with a defense to the original charge. Where is the line to be drawn between Judge Hand's "Justice is not a game" and the "manifest injustice" of the Rule?

Withdrawal of a plea of guilty will be allowed if, at the time he entered the plea, the defendant did not have the requisite understanding of the charges against him or of the consequences of his plea. ${ }^{12}$ This rule, however, has not been applied consistently. In United States $v$. Weese $e^{13}$ perpetration of a fraud upon the defendant by the court or prosecution was said to be necessary to support a motion for withdrawal. The rule announced in Rachel v. United States was slightly broader-the "reason must amount to a fraud or an imposition upon [the defendant], or a misapprehension of his legal right...."14 There is a dictum in United States v. Sehon Chinn $2^{15}$ that the misrepresentation or misapprehension must have been induced by the prosecution or the defendant's motion will not be granted. A broader interpretation is found in three other cases, Bergen v. United States, ${ }^{16}$ United States v. Schneer, ${ }^{17}$ and United States v. Lias. ${ }^{18}$ In the Bergen case the defendant had admitted soliciting bankruptcy cases under the Frazier-Lemke Act; he had not understood that a specific intent to defraud the government was necessary for conviction. The court granted relief under Rule 32(d) because of the defendant's misconception of the law. The defendant was not represented by counsel at the time of the original plea, and the court seemed more ready to extend leniency in such a situation. The Schneer case involved a

12 Gannon v. United States, 208 F. 2d 772 (C.A. 6th, 1953); United States v. Panebianco, 208 F. 2d 238 (C.A. 2d, 1953); Ridgeway v. United States, 205 F. 2d 680 (C.A. 6th, 1953); United States v. Schneer, 105 F. Supp. 883 (E.D. Pa., 1952); Williams v. United States, 192 F. 2d 39 (C.A. 5th, 1951); United States v. Lias, 173 F. 2d 685 (C.A. 4th, 1949); Losieau v. United States, 177 F. 2d 919 (C.A. 8th, 1949); Bergen v. United States, 145 F. 2d 181 (C.A. 8th, 1944); United States v. Weese, 145 F. 2 d 135 (C.A. 2d, 1944); United States v. Colonna, 142 F. 2d 210 (C.A. 3d, 1944); United States v. Denniston, 89 F. 2d 696 (C.A. 2d, 1937); Rachel v. United States, 61 F. 2d 360 (C.A. 8th, 1932).

is 145 F. 2d 135 (C.A. 2d, 1944).

1461 F, 2d 360, 362 (C.A. 8th, 1932) (italics added).

1574 F. Supp. 189 (S.D. W.Va., 1947), aff'd 163 F. 2d 876 (C.A. 4th, 1947).

16145 F. 2 d 181 (C.A. 8th, 1944).

${ }^{17} 105$ F. Supp. 883 (E.D. Pa., 1951), aff'd 194 F. 2d 598 (C.A. 3d, 1952), motion granted 105 F. Supp. 883 (E.D. Pa., 1952).

18173 F. $2 d 685$ (C.A. 4th, 1949). 
representation, originally the prosecutor's but repeated more convincingly by the defense attorney, that the defendant would not go to jail. Relief was first denied by the district court on the ground that an assistant United States attorney's representation was not binding upon the court, and the defense attorney, knowing this, nonetheless advised the plea. The court of appeals affirmed, but without prejudice to further proceedings by the defendant to offer additional proof and clear up ambiguities in the record. In a rehearing in the district court the defense attorney testified forcefully about his representation to his client that no one had ever been sent to jail for that crime in the district involved. The court found that the defendant had reasonably relied upon the representation and felt that the interests of justice required that he be given a trial on the merits. The Lias case provides strong precedent for such a result. The defendant had been misled by a conversation between his attorney and the judge about the possibility of probation. The motion to withdraw the plea was granted, and on appeal by the prosecution the court quoted the district judge with approval: "the court has to take that belief into consideration, irrespective of the kind of information upon which it was founded."19 The court thus emphasized the nature of the defendant's misconception.

Other cases, stressing the source of the misconception, have refused relief where the misconception is traceable not to the prosecution but to the defense counsel. In Futterman v. United States, ${ }^{20}$ the defendant alleged that his counsel's erroneous advice had convinced him that he was guilty when in reality he was not; the attorney in question flatly denied this by affidavit. The court held that the attorney's representations were words of "hope and not of promise,"21 and the motion was denied. In United States v. Searle $e^{22}$ the representations were more nearly words of promise. The attorney there told the defendant that the odds were "one thousand to one"23 against his going to jail as a result of his plea. The motion was denied in the district court and the denial affirmed in the court of appeals. The court felt the question involved the judgment of the attorney; since the attorney was competent and had thoroughly investigated the case, the court would not now grant a withdrawal because he happened to have been wrong. The representation by the defendant's attorney in United States v. Parrino ${ }^{24}$ was also thought to involve an element of judgment. The defendant had pleaded guilty, relying on his attorney's erroneous advice that a conviction based on his guilty plea would not subject him to deportation. Threatened with deportation proceedings, the defendant moved to withdraw his plea. The court denied his motion on the ground that he was merely surprised at the results of his plea. A vigorous dissent by Judge Frank pointed out that he might not have

${ }^{19}$ United States v. Lias, 173 F. 2 d 685, 687 (C.A. 4th, 1949).

20202 F. 2d 185 (App. D.C., 1952).

${ }^{21}$ Ibid., at 186.

22180 F. $2 d 209$ (C.A. 7th, 1950).

${ }^{23}$ Ibid., at 210.

24212 F. 2d 919 (C.A. 2d, 1954). 
entered the plea had he not been misled as to the consequences by the advice of his attorney. ${ }^{25}$

The conflict of purposes underlying the federal rule is illustrated by these cases. It seems unjust to hold to their pleas all defendants who plead guilty relying on a mistake or misrepresentation of their counsel. Yet an interpretation of the rule which would permit wholesale withdrawals would encourage unscrupulous attorneys to begin every criminal case with a guilty plea as a "trial balloon." 26 This practice would not only encourage perjury ${ }^{27}$ but would extend to defendants the anticipated advantage of a guilty plea (leniency of sentence) while retaining the possibility of a jury trial on the merits.

Two suggestions for resolving the problem of reliance on a mistake or misapprehension of defendant's counsel have been advanced. The first is that a distinction be drawn between an error of judgment and a palpable mistake of the defense attorney. ${ }^{28}$ In addition to the difficulty in drawing this distinction, such a solution fails to meet the problem of the calculated "mistake." The second approach would distinguish between counsel appointed by the court and counsel of the defendant's own choosing. ${ }^{29}$ This does not meet the problem squarely, for the injustice to the defendant can be equally manifest in either case.

A further problem presented by a rule drafted in terms of justice is the relevance or necessity of allegations or proof of the defendant's innocence. Some cases hold that such an allegation or offer is a prerequisite to the granting of a motion to withdraw; $;^{30}$ other cases hold that no question of guilt or innocence

${ }^{25}$ In fairness to the attorney in the case it must be said that his misrepresentation of the law may have been in the best interests of his client. Had he elected to stand trial the result might have been a death sentence or a long prison term followed by deportation. After the guilty plea was entered to the conspiracy count in the indictment, as a result of which the defendant served a two-year sentence and faced deportation, the prosecution dropped the substantive count which could have resulted in a far more serious sentence. See the opinion of Judge Learned Hand in United States v. Parrino, 180 F. 2d 613 (C.A. 2d, 1950).

${ }^{26}$ United States v. Weese, 145 F. 2d 135, 136 (C.A. 2d, 1944).

${ }^{27}$ The attempt by an attorney to secure for his client two days in court, one on the plea, and, if the defendant is not satisfied, another on a subsequent trial obtained through a motion to withdraw, could be based only on the perjured testimony of the defense counsel or witnesses coached by the defense counsel.

${ }^{28}$ See the dissenting opinion of Judge Frank, United States v. Parrino, 212 F. 2d 919, 925 (C.A. 2d, 1954).

${ }^{29}$ The courts tend to extend more leniency to defendants who are represented by courtappointed counsel. See Losieau v. United States, 177 F. 2d 919 (C.A. 8th, 1949). Where the defendant is not represented by counsel at all an attempt to withdraw the plea can raise a constitutional question under the Sixth Amendment. Often the regularity of the procedure by which the right to counsel was waived will be controlling. A defendant, however, cannot expect sympathetic treatment from the court simply because he is not represented. Compare Gannon v. United States, 208 F. 2 d 772 (C.A. 6th, 1953), with Stidham v. United States, 170 F. 2d 294 (C.A. 8th, 1948).

${ }^{30}$ United States v. Paglia, 190 F. 2d 445 (C.A. 2d, 1951); United States v. Norstrand Corp., 168 F. 2d 481 (C.A. 2d, 1948); Cantwell v. United States, 163 F. 2d 782 (C.A. 4th, 1947). Cf. United States v. Harris, 160 F. 2d 507 (C.A. 2d, 1947). 
is involved. ${ }^{31}$ In Kercheval v. United States, ${ }^{32}$ the Supreme Court in deciding that a plea which had been withdrawn could not be used in evidence against the defendant on his subsequent trial intimated that the granting of a motion to withdraw should not depend on guilt or innocence. The court's discretion should be exercised for a "fair and just reason." A second case indicating that innocence is immaterial to the disposition of the motion is Friedman v. United States. ${ }^{33}$ The motion under Rule 32(d) was denied because the defendant's only real concern was with the severity of his sentence and the question of guilt was discussed only because the defendant alleged his innocence.

In four cases there has been an inquiry into the merits of the defendant's allegation of innocence; ${ }^{34}$ in all four a finding for the prosecution on this issue substantially disposed of the motion. In the most recent, United States $v$. Shailer, ${ }^{35}$ the defendant was charged with stealing an automobile. His motion proceeded on three premises: that he had been misled about the severity of the penalty, that the United States attorney had applied undue pressure on him to enter the guilty plea, and that title to the car had passed to him and he was therefore not guilty of the offense charged. The district court found that the first two premises were groundless in fact; hence appeal was taken only on the last. The Court of Appeals for the Second Circuit, in an opinion by Judge Frank, examined the facts and ruled that title to the car had not passed. Since the defendant had not established his innocence, he had not suffered "manifest injustice."

The cases reveal that allegations of innocence have never stood alone in support of a motion, but have been helpful only insofar as they have accompanied other facts which tended to show "manifest injustice." In the Schneer case, ${ }^{36}$ where the defendant had relied on a misrepresentation of his attorney that he would not go to jail for the offense involved, the motion to withdraw the plea of guilty was granted. Allegations asserting technical defenses (defective indictment and statute of limitations), although not controlling, undoubtedly helped to create a context which seemed manifestly unjust.

When a defendant bases his claim of manifest injustice solely on the ground that he is innocent, it would be reasonable, perhaps, to resolve his claim by a consideration of the facts he presents. ${ }^{37} \mathrm{~A}$ very different question is involved in

31 E.g., Friedman v. United States, 200 F. 2d 690 (C.A. 8th, 1952). See Kercheval v. United States, 274 U.S. 220 (1926).

32274 U.S. 220 (1926).

${ }^{32} 200$ F. 2d 690 (C.A. 8th, 1952). See page 731 supra.

${ }^{34}$ United States v. Shailer, 202 F. 2d 590 (C.A. 2d, 1953); Stidham v. United States, 170 F. 2d 294 (C.A. 8th, 1948); United States v. Achtner, 144 F. 2d 49 (C.A. 2d, 1944); United States v. Sehon Chinn, 74 F. Supp. 189 (S.D. W.Va., 1947), aff'd 163 F. 2 d 876 (C.A. 4th, 1947). ${ }^{35} 202$ F. 2d 590 (C.A. 2d, 1953).

${ }^{36}$ United States v. Schneer, 105 F. Supp. 883 (E.D. Pa., 1951), aff'd 194 F. 2 d 598 (C.A. 3d, 1952).

${ }^{37}$ The reasonableness of this procedure might be questioned, however. An appellate court passing on a motion to withdraw a guilty plea is not the proper tribunal to pass upon the facts determining guilt or innocence. 
determining whether a defendant must allege his innocence in addition to other grounds for withdrawal. In a society which considers lack of due process a form of injustice, irrespective of the guilt or innocence of the person involved, allegations of innocence would seem unnecessary.

There is some question as to whether a subsequent change in the law governing the offense will support a defendant's motion for withdrawal of his guilty plea, which was made under the old law. Doubtless circumstances could arise in which this would be permitted, but none has occurred as yet. In United States v. Vidaver ${ }^{38}$ the court analyzed the defendant's contention that a change in the law subsequent to his plea offered him a complete defense. Upon finding that it did not, the court denied the motion. United States v. Western Chemical \& Mfg. Co. ${ }^{39}$ a case involving violations of a war food order, was contested on the same point, the court there allowing withdrawal of the plea with respect to some violations while denying it with respect to others. ${ }^{40}$ The case is perhaps typical of all litigation under Rule 32(d) in that it contains little in the way of precedent value but achieves an equitable result.

Rule 32(d) contains no time limit nor have the courts inferred one.4I Cases arising under the Rule, however, show that the courts have taken into consideration the defendant's delay in asserting his motion. The credibility of the defendant and the reasonableness of the grounds upon which he has elected to move have been doubted when the defendant could not adequately explain his delay. In United States v. Mignogna $a^{42}$ the defendant's claim that he was held in "maximum confinement" and was therefore unaware of the full extent of his rights was not an adequate explanation of his seven months' delay in bringing his motion. The court understandably wondered in United States v. Sehon Chinn ${ }^{43}$ why the defendant had waited three years to attempt to withdraw his plea on the ground that he was misled by his counsel, who, coincidentally, had died in the meantime. The delay in United States v. Parrino, ${ }^{44}$ on the other hand, could not have affected the result since it was satisfactorily explained. The defendant, who had completed his two-year sentence before moving to withdraw his plea, had not realized that conviction on his guilty plea would subject him to depor-

3873 F. Supp. 382 (E.D. Va., 1947). 3978 F. Supp. 983 (S.D. Cal., 1948).

${ }^{40}$ Defendant had violated the order at a time when its validity was unquestioned. A similar allocation order was subsequently held invalid in Fleming v. Moberly Milk Products Co., 160 F. 2d 259 (App. D.C., 1947), cert. denied 331 U.S. 786 (1947), and the government then dropped prosecutions under the order involved here as to violations which had occurred after September, 1945. Since the court felt that the defendant should not obtain a competitive advantage over the other firms as a result of violating the order in a time of national emergency, the motion to withdraw the plea was allowed only insofar as violations after September 1945 were concerned. Withdrawal was denied with respect to the earlier violations.

${ }^{41}$ This is the major difference between Rule 32(d) and its predecessor, Rule II(4). Consult Whitman, Federal Criminal Procedure 239 (1950).

42157 F. 2d 839 (C.A. 2d, 1946).

4374 F. Supp. 189 (S.D. W.Va., 1947), aff'd 163 F. 2 d 876 (C.A. 4th, 1947).

4212 F. 2d 919 (C.A. 2d, 1954). 
tation-he could not have known he was subject to deportation before proceedings were actually begun. ${ }^{45}$

The extent to which the discretion of the trial court is reviewable appears to involve a conflict of authority. Two early cases seem to indicate that the trial court's discretion is final, but neither case appears to be good authority. In Farrington $v$. King ${ }^{46}$ the court said that the motion was not appealable, but the lapse of time between the plea and the motion enabled the court to deny the motion on that ground under the predecessor of Rule 32(d). In Billingsley v. United States, ${ }^{47}$ which antedated both the Federal Rules of Criminal Procedure and the old rules of 1933, there was language to the effect that the decision on the motion was not reviewable. The court, however, did examine the defendant's contentions, concluding that "there is absolutely nothing here to indicate in the smallest particular that the court abused its discretion in denying [the motions]." ${ }^{48}$ More recent cases allow a limited degree of appellate review. ${ }^{49} \mathrm{It}$ would appear well settled today that the denial of a motion to withdraw a guilty plea is subject to review providing the defendant can satisfy the appellate court that the trial court abused its discretion..$^{50}$

In exercising their discretion under Rule 32(d) to allow the withdrawal of a guilty plea, the federal courts have been guided by the mandate of the Rule "to correct manifest injustice." They have construed the Rule broadly to aid defendants who have acted in good faith, but have discouraged any attempt to rely on the Rule as a tactical device to secure the most favorable disposition of the case. Federal courts, in summary, have weighed the equities of each case and have avoided formulating rigid categories prescribing conditions which

45 This is precisely the type of situation in which the old rule operated harshly. Consult Orfield, Improving Procedure on Judgment and Appeal in Federal Criminal Cases, 2 F.R.D. 573,577 (1942). Professor Orfield, however, merely suggested that the old rule be changed to permit withdrawal at any time before sentence in the discretion of the court. He did not consider the post-sentence motion. While the old rule was in force the courts did give effect to the time limitation. Hood v. United States, 152 F. 2d 431 (C.A. 8th, 1946); United States v. Swift, 148 F. 2d 361 (App. D.C., 1945); United States v. Weese, 145 F. 2d 135 (C.A. 2d, 1944). In United States v. Achtner, 144 F. 2d 49 (C.A. 2d, 1944), the court considered an untimely motion on the merits and found for the prosecution, then gave effect to the time limitation. In Farrington v. King, 128 F. 2d 785 (C.A. 8th, 1942), the court's alternative ground was a rather doubtful conclusion that the disposition of the motion below was not subject to appeal.

46128 F. 2 d 785 (C.A. 8th, 1942).

47249 Fed. 331 (C.A. 9th, 1918).

48 Ibid., at 332.

49 Williams v. United States, 192 F. 2d 39, 40 (C.A. 5th, 1951): "Such a motion is addressed to the sound, but reviewable, discretion of the trial court"; United States v. Panebianco, 208 F. $2 d 238$ (C.A. 2d, 1953); Friedman v. United States, 200 F. 2d 690 (C.A. 8th, 1952); United States v. Schneer, 194 F. 2d 598 (C.A. 3d, 1952); Smith v. United States, 180 F. 2d 851 (C.A. 6th, 1950); United States v. Searle, 180 F. 2d 209 (C.A. 7th, 1950); Mitchell v. United States, 179 F. 2 d 305 (C.A. 5th, 1950); Cantwell v. United States, 163 F. 2d 782 (C.A. 4th, 1947); Katz v. United States, 161 F. 2d 869 (C.A. 6th, 1947).

${ }^{50}$ But where there is a conflict of evidence the trial court's resolution of the conflict is not reviewable. United States v. Rosensweig, 144 F. 2d 30 (C.A. 9th, 1944); Losieau v. United States, 17 F. 2d 919 (C.A. 8th, 1949). 
must be fulfilled before a motion can be granted. As a result the criminal law has been provided with a workable solution by which the consequences of an ill-considered plea can be avoided.

\section{REGULATION AND TAXATION OF HOUSE TRAILERS}

The use of house trailers by more than one million Americans ${ }^{1}$ has created a growing problem for local government. An influx of house trailers may bring health and sanitation problems, traffic congestion, and ugly vistas to a community. Property values may be adversely affected; governmental costs are inevitably increased. In addition, it is thought that trailer dwellers make little financial, civic, or political contribution to community life. Trailers are thought to be occupied by rootless wanderers and are commonly regarded as posing threats to community interest not presented by other types of housing. The combination of all these dangers, real and imaginary, has been the source both of legitimate attempts to regulate the use and location of trailers and of hostile measures which have no similar justification. ${ }^{2}$

This comment will examine the extent to which the problems created by the mobile home have been solved in consonance with the legitimate interests of both trailer dweller and community. The discussion is divided into two areasthe regulation of trailers, and the raising of revenue to meet the social cost occasioned by the mobile-home population. ${ }^{3}$

1 America's house-trailer population has grown rapidly in the last twenty-five years. In 1930 trailer sales amounted to only $\$ 1,300,000$; by 1945 the figure was $\$ 39,000,000$, and in $1953 \$ 321,000,000$ worth of house trailers were sold. Trailers range in price from $\$ 2,800$ to $\$ 7,000$. Mobile Homes Manufacturers Ass'n, Homes for the Mobile Population (1954), and Third Annual Report (1953). Their accommodations include complete kitchen, bedroom, and sanitary facilities with tub, shower or both. Many models also contain such luxury furnishings as built-in television, built-in air-conditioning, and automatic garbage-disposal units. The average income of families buying new mobile homes in 1953 was approximately $\$ 1,100$ above the national average. Marketing Information Associates, Mobile Homes Sales Story 34 (1954). Of the total trailer population, 59 per cent of the families attend church regularly, and 75 per cent of the adult occupants are registered voters. The same survey also revealed that 63 per cent are mobile or semi-mobile occupation workers; 20 per cent are military personnel; 10 per cent are retired persons; and "all others" total 7 per cent. Mobile Homes Manufacturers Ass'n, Homes for the Mobile Population (1954).

2 While hostility to trailers is not openly admitted, its existence cannot be questioned. One locality completely excluded trailers, Commonwealth v. Amos, 30 Del. Co. (Pa.) 552 (1941) (invalidating the exclusion), by a statute also dealing with "gypsies." Municipalities have attempted to uproot trailer dwellers who had lived in the community for years. City of East Point v. Minton, 207 Ga. 495, 62 S.E. 2d 911 (1951). The city's counsel in Cady v. City of Detroit, 289 Mich. 499, 286 N.W. 805 (1939), asserted that trailer living tends to cause immorality among trailer children. In connection with the transiency provision in the Cady case, the court stated: "Ordinances having for their purpose regulated municipal development, the security of home life ... the stabilization of the use and value of property, the attraction of a desirable citizenship and fostering its permanency are within the proper ambit of the police power." Ibid., at 514, 810 (italics added). In Gust v. Township of Canton, 337 Mich. 137,59 N.W. 2d 122 (1953), a town clerk testified that the local townspeople had pressured him to eliminate the trailers within the community.

${ }^{3}$ The revenue problem became pre-eminent only after regulatory obstacles were hurdled. Until the 1930's the amount of trailer housing was negligible. The sudden boom in mobile 